\title{
Effects of language proficiency and contextual factors on second language learners' written narratives: A corpus-based study
}

\section{Dosi, Ifigeneia}

Democritus University of Thrace, Greece (idosi@ helit.duth.gr)

Douka, Gerakini

Aristotle University of Thessaloniki, Greece (dgerakini@lit.auth.gr)

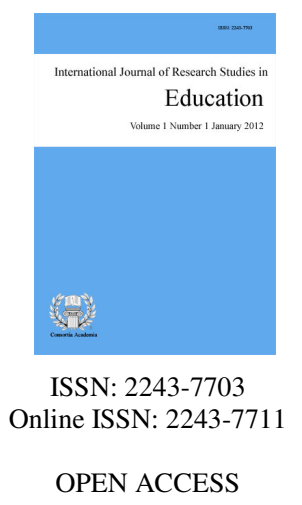

Received: 30 November 2020

Revised: 7 December 2020

Available Online: 24 January 2021 DOI: $10.5861 /$ ijrse.2021.5076

Accepted: 20 January 2021

\section{Abstract}

The current study is a corpus-based study that investigates (a) written narrative productions of second language (L2) learners regarding aspects of both macrostructure and microstructure and (b) the effects of linguistic and contextual factors on the written narratives. Narratives are a useful tool since they depict children's communicative, linguistic and cognitive abilities. Recent studies in L2 learners exhibited that both macrostructure and microstructure are linked with language proficiency, cognitive abilities and contextual factors (e.g. input and literacy practices). The present study examined macro- and microstructural aspects of 91 written narratives of L2 learners of Greek with Albanian origin by means of the Greek Learner Corpus. The results showed that language proficiency affects both macrostructure and microstructure. In addition, noun diversity correlated with literacy support in both languages and residence in the host country. The outcomes have further pedagogical implications and they also suggest that literacy should be supported in both languages in order to increase L2 learners' linguistic abilities.

Keywords: second language learners; written narratives; macrostructure; microstructure; language proficiency; literacy; corpus-based study 


\section{Effects of language proficiency and contextual factors on second language learners' written narratives: A corpus-based study}

\section{Introduction}

The increasing number of recent studies investigating oral and written narrative skills in bilingual children and second language (L2) learners indicate the growing interest of the scientific and educational community in narrative analysis, since it is considered an ecologically valid way to explore children's communicative competence (Botting, 2002) as well as various linguistic, cognitive and social abilities (Tager-Flusberg \& Sullivan, 1994). Narrative skills are usually analyzed under two axes: macrostructure and microstructure. The former refers to the so-called global coherence of a narrative (e.g. setting the time and place, the characters and the episodes of the story) while the latter concerns the local coherence (e.g. lexical and syntactic complexity) (Gagarina et al., 2012).

With regard to the factors that seem to explain at least a part of the variance attested in L2 storytelling, increased language proficiency has found to improve narrative production, in particular narrative structure and cohesion, in both bilingual and L2 children, although there is an ongoing debate about whether a necessary threshold needs to be reached for the advantages to appear (Montanari, 2004; Viberg, 2011). Additionally, contextual factors, and particularly emergent literacy (i.e. home literacy/parental book reading, in line with schooling/kindergarten), are also considered to enhance children's narrative skills (Snow \& Dickinson, 1990; Cain, 2003; Gorman et al., 2011; Karlsen et al., 2016).

Further expanding our understanding about the factors affecting narrative productions in L2, the present study investigates, by means of the Greek Learner Corpus (GLC; Tantos \& Papadopoulou, 2014), the written narratives generated by young L2 learners with Albanian as their first language (L1) and Greek as their L2. For the purposes of this study aspects of macrostructure and microstructure were analyzed. More specifically, Story Grammar (a series of events in a story) and aspects of lexical and syntactic complexity (i.e., verb and noun diversity, content and function words and main and subordinate clauses) were examined in relation to (a) linguistic factors (i.e. L2 proficiency) and (b) contextual factors (i.e., years of residence in Greece and years of attendance at Greek and Albanian educational setting). We believe that the present study adds value to the existing work on L2 written narratives and can have further pedagogical implications, since it will inform teachers and language instructors about learners' written narrative abilities and about the factors affecting them.

\section{Bilingualism and second language acquisition}

Bilingualism is affected by numerous parameters, and therefore it is accompanied by great diversity (Grosjean, 1989). In short, the Age of Onset of L2 acquisition, input, literacy in both languages (biliteracy) and socioeconomic status are factors that are found to have an impact on linguistic and cognitive development (for a review see Andreou, 2015).

A ge of L2 onset is a crucial factor since it is often used to determine the different types of bilinguals. Nonetheless, there is no consensus among researchers regarding the age range and the age criteria. Meisel (2009) claimed that simultaneous bilinguals are considered the speakers who have been exposed to the two languages from birth while sequential/successive bilinguals are those who were exposed at a later age. More specifically, early sequential/successive bilinguals were exposed to the L2 from 1 to 4 years and late sequential/successive bilinguals were exposed to the L2 from year 4 onwards.

By contrast, Rothweiler (2006) suggested a stricter perspective, arguing that when a child is exposed to the L2 at school age is considered an L2 learner. Similarly, Grosjean (1989) and De Houwer (1995) noted that 
children who are exposed to both languages from birth or to the L2 up to the age of 3 are considered as simultaneous bilinguals, while children who are exposed to the L2 from 3 to 7 years old are called sequential/successive bilinguals. The second group is further subdivided to early (3-4 years old) and late sequential/successive bilinguals (4-7 years old). The stricter perspectives are based on the so-called Critical Period Hypothesis (Lenneberg, 1967) and the gradual decrease in our ability to acquire an L2 to native-like levels (e.g. age 7-8 years; Johnson \& Newport, 1989). According to other researchers (Schwartz, 2004; Unsworth, 2005) a valid criterion to discriminate between L2 and bilingual acquisition may be that the main features and core structures of the L1 grammar have been settled down before regular exposure to the L2 starts. Continuing this line of reasoning, many studies have found that L2 children acquire language similarly to L2 adults whereas simultaneous and early successive bilinguals acquire language in a similar fashion to monolinguals (Kroffke \& Rothweiler, 2006; Meisel, 2008, 2009; Sopata, 2010).

Both in bilingualism (Chondrogianni \& Marinis, 2011; Bedore et al., 2012; Unsworth, 2014, 2016) and in L2 acquisition (Viberg, 2001), studies have shown that quality and quantity of input affect language acquisition. Studies in bilingualism have also verified that biliteracy and bilingual educational setting positively affect the acquisition of both languages (Bongartz \& Torregrossa, 2017; Andreou \& Tsimpli, 2020). According to Cummins (1976, 1979) bilingual speakers transfer skills across languages ("interdependence theory" and "common underlying proficiency"), especially as far as literacy is concerned. In other words, once bilinguals have acquired basic literacy skills in their L1 and they have also developed communicative abilities in the L2 they transfer the literacy skills from L1 to L2. In a similar vein, in a study of Andreou and Tsimpli (2020) findings suggested that the lack of literacy support in L1 negatively affected the literacy development in L2 since, conceivably, transfer of abilities from L1 to L2 was impeded, due to the unequal literacy support between the two languages. Durgunoğlu (2002) as well noted the importance of transfer from L1 to L2 Transfer of skills between languages is also discussed by Bongartz and Torregrossa (2017) who focus on narrative skills; According to them, the ability to produce coherent narrative discourse is considered one of the best indicators of literacy skills and academic language proficiency. Their findings pointed out that low language proficiency, in line with unbalanced literacy, leads to reduced performance in narrative discourse. By contrast, balanced literacy practices can counterbalance the low proficiency level and facilitate the transfer of narrative skills between the two languages. Recent studies have shown that literacy also plays and important role in L2 learners (Rydland et al., 2014; Squires et al., 2014; Karlsen et al., 2016). Thus, emergent literacy (shared-book reading) is also positively correlated to language development.

\section{Narratives}

\subsection{Primary and secondary discourse ability}

An interesting distinction for the purposes of the current study is the one between primary and secondary discourse ability (Francis, 2006). Primary discourse ability underlies children's everyday narrations that are generated in a specific context and are, thus, built on shared background knowledge with the interlocutor. This kind of storytelling consists of an unstructured sequence of events and usually lacks strong cohesive ties (Bongartz \& Torregrossa, 2017). What is more, this early narrative along with core linguistic knowledge is considered "universally attainable" (Francis, 2006, p. 42).

On the other hand, secondary discourse ability refers to the transition from basic, situation-embedded conversational speech to carefully structured and decontextualized narrations. Apart from the increase in the use of cohesive mechanisms, this kind of discourse demands a high effort to maintain the narration as clear and unambiguous to the interlocutor as possible (Bongartz \& Torregrossa, 2017). Additionally, late (Francis, 2006) or schooled (Fang, 2001) narratives, requiring developed competencies (or knowledge structures) in the level of discourse, are largely interdependent with advanced information-processing skills and metalinguistic awareness (Francis, 2006). Since the latter is primarily fostered in school setting, secondary discourse ability is said to be 
considerably prone to growing variation in typically developing children.

It is exactly this variation that is investigated by means of elicited narratives for the purposes of research in the field of psycholinguistics and education.

\subsection{Narratives as a tool}

Narratives can be either oral or written and they can be elicited by means of pictures or video. Furthermore, they can be produced either in a telling or in a retelling mode: in the former, participants look at the pictures or watch the video and are asked to create a story on their own while in the latter, they hear the story before they are asked to reproduce it. In general, telling is more difficult for children than retelling, while according to Andreou (2015) retelling has been found to boost participants' performance and increase the length and complexity of their narratives (e.g. the use of subordinate clauses).

Narratives are usually analyzed based on two main components: microstructure and macrostructure, as introduced by Kintsch and van Dijk (1978), which are said to be two separate but interdependent areas underlying narrative discourse competence (Liles et al., 1995).

Microstructure concerns a narrative's sentence level and is explored by means of various measures of lexical and syntactic complexity (Hughes et al., 1997). For instance, microstructural aspects denote narrative length, number of content and function words, number of main and subordinate clauses, use of tense, aspect, voice, inflectional morphology etc. (Miller, 1981; Scott \& Stokes, 1995; Schuele \& Tolber, 2001; Nippold et al., 2005). Microstructure also pertains to lexical diversity (Templin, 1957).

On the other hand, macrostructure refers to a language independent higher-order hierarchical organization of the story (Pearson, 2002; Heilmann et al., 2010) and, according to the Story Grammar model (Stein \& Glenn, 1978), denotes participants' ability to successfully handle and transmit the setting of the story, i.e. information about the time and the place and introduction of the main characters and its episodes. More specifically, each episode is said to consist of the following basic elements: (a) a goal the protagonist sets in order to respond to an external event, (b) his/her attempt to accomplish this goal and (c) the outcome of his/her attempt, i.e. the success or failure in achieving his/her goal and solving the problem that initially motivated his/her action (McCabe \& Peterson, 1984; Schneider et al.; Gagarina et al., 2012).

Apart from the establishment of the story's context and the arrangement of its episodic structure, Hickmann (2004) and Andreou (2015) add to a story's macrostructure the component of referential cohesion, i.e. character introduction and maintenance throughout the story with the use of various linguistic devices, as well as the Theory of Mind ability (Premack \& Woodruff, 1978), in terms of presenting the characters' mental state representations (i.e. feelings, intentions and beliefs; cf. Stein \& Glenn, 1978; Curenton \& Justice, 2004).

After having introduced the basic concepts in the use of narratives for the investigation of secondary discourse ability, we now turn to the studies having used this methodology to explore variation in L2 narrative productions.

\subsection{Factors affecting narrative skills}

Many studies have indicated proficiency in L2 as one of the most pivotal factors for successful storytelling. Although studies use different ways to measure proficiency, the most reliable factor was found to be grammatical knowledge and not vocabulary knowledge (Bedore et al., 2012). What is more, proficiency has also been found to act in combination with contextual factors (Karlsen et al., 2016), which will be further analyzed later.

With regards to proficiency, it is important to mention that most of the research outcomes suggested that linguistic proficiency and macro- and microstructural features of narrative production correlate once a certain level of proficiency in L2 has been reached (Montanari, 2004; Viberg, 2011), as Cummins $(1976,1979)$ also

4 Consortia Academia Publishing (A partner of Network of Professional Researchers and Educators) 
suggested. However, evidence against a strong interdependence between children's proficiency and macrostructure is offered by Gutiérrez-Clellen (2002) who claim that participants, despite their low level of grammatical knowledge in the L2, managed to produce efficient and coherent stories.

Turning to contextual factors, there seems to be a reciprocal positive influence between narrative and literacy practices. In detail, a vast majority of studies have linked storytelling efficiency with the development of literacy skills, reading abilities and school success (McCabe \& Rollins, 1994; McCabe, 1996; Bliss et al., 1998; Gutiérrez-Clellen, 2002; Swanson et al., 2005; Miller et al., 2006; Walach, 2008; Bongartz, 2016; Gagarina, 2016) since children's experience with oral discourse prepares them to more readily understand and accept the written texts conventions that are going to encounter during their schooling (Hadley, 1998; Westby, 2005).

On the other hand, parental book reading (i.e. emergent literacy) has been found to have a positive impact on children's language development (Teale \& Sulzby, 1986; Bus et al., 1995; Leseman \& de Jong, 1998), and narrative production skills, regardless of the socioeconomic status of the speakers (Evans et al., 2010), since it helps children become familiar with story structure (Snow \& Dickinson, 1990; Cain, 2003). Furthermore, as mentioned earlier, Karlsen et al. (2016) have found evidence that proficiency in combination with home literacy and exposure to L2 in kindergarten predict performance in microstructure measures.

Thus, schooling, i.e. kindergarten, has also been found to enhance children's narrative skills (Gorman et al., 2011). Finally, Karlsen et al. (2016) have also found evidence that contextual factors along with cognitive abilities strongly correlate with performance in macrostructure.

Karlsen et al. (2016) conclude their study highlighting the need for further research concerning the impact of different linguistic, contextual and cognitive factors on both L1 and L2 narrative productions. Our study aims at contributing to this discussion and providing more evidence on the way these factors explain variation in storytelling. For this purpose, factors such as proficiency in L2, as well as the time spent in Greek and Albanian educational setting are included in the analyses.

\section{The present study}

We set out to investigate, by means of the Greek Learner Corpus (GLC; Tantos \& Papadopoulou, 2014), the role of language proficiency and contextual factors in aspects of both macrostructure and microstructure in written productions of L2 learners with Albanian origin.

Our first research question concerned the impact of language proficiency on aspects of the two main narrative components, macro- and microstructure, the main prediction being that language proficiency would indeed affect them (Montanari, 2004; Viberg, 2011); hence the more proficient the student, the better stories they would give and the more complex sentences and more divergent vocabulary they would use.

Our second research question was whether contextual factors would correlate with narrative skills. Thus, we expected that input (Viberg, 2001) and literacy practices (Karlsen et al., 2016) would correlate with the performance in macrostructure and microstructure, since more input and higher literacy would lead to a more complete storytelling, to the use of more complex structures and greater noun and verb diversity.

\subsection{Greek Learner Corpus (GLC)}

The data analyzed in the present study are part of the Greek Learner Corpus (GLC), compiled within the framework of the three-year (2010-2013) project "Education of Foreign and Repatriated Greek Students", funded by the European Union and the Greek Ministry of Education, Lifelong Learning and Religious Affairs. ${ }^{1}$ GLC consists of written productions of learners in primary and secondary education levels (Tantos \& Papadopoulou, 2014), with a great variety of first languages, the most common of which are Albanian, Slavic

${ }^{1}$ http://www.diapolis.auth.gr/ 
languages, Georgian, Arabic, Hindi and Urdu (Tantos \& Papadopoulou, 2014), with Albanian being also the most common overall (46\%). The corpus includes around 500 written productions (approximately 33,000 words) by 329 students (males, $n=211$ and females, $n=118$ ) studying in reception classes in public schools all over Greece. All participants were recruited from public schools in Greece. Moreover, all data were collected after children's parents gave their written consent. The study received the approval of the Research Ethics Committee of the Greek Ministry of Education and the Institution of Educational Policy in Greece.

All the texts included in the GLC are annotated for learners' errors which are separated in two main categories (following Dulay et al., 1982): (a) linguistic errors (e.g. determiners, tense, aspect) and (b) error performance (e.g. omission, addition, substitution; see Tantos \& Papadopoulou, 2014). Nonetheless, the productions were not annotated regarding macro- and microstructure. Finally, it is important to mention that the corpus is accompanied by a metadata file containing useful information about learners' age, L1, years of residence in Greece, years in the Greek educational system and years in another's country educational system.

\subsection{Participants}

For the purposes of the present study, only the texts generated by Albanian speaking L2 learners of Greek were used since, as noted earlier, they consisted the numerically largest language group of the corpus $\left(159^{2}\right.$ out of 319 students) and we wanted to avoid any differences that might arise from different L1s. Before going on to present participants' profile, we should underline that, following the classification of Rothweiler (2006), Grosjean (1989) and De Houwer (1995), as noted earlier in section 2, for the purposes of the present study participants are considered as L2 learners, and not as bilingual speakers, since they have been exposed to Greek language after the age of seven.

It is worth noting that the Albanian speaking community consisted at the time of the data collection the largest immigrant community in Greece, according to the Press Release of the Hellenic Statistical Authority (2014). Albanian immigrants arrived in Greece mostly during the late 80's and early 90's due to political upheaval. The children of the present study are children of these immigrants. Hence, the participants that were included in the study were 91 Albanian-speaking learners (59 males and 32 females), studying Greek as a second language at the reception classes of the Greek public schools, during the school period 2011-2012 $2^{3}$. Specifically, the participants were either third to sixth graders of elementary school or students of the first three grades of high school (aged 8-18 years; mean age: 11.5 years).

Students' proficiency in Greek was assessed by means of two ${ }^{4}$ standardized placement tests of increasing difficulty, the first administered to learners in the third and fourth grade of primary school and the second one to fifth and sixth graders and high school students. The placement tests were designed based on a revised version of CEFR scale (Council of Europe 2001) that was adapted in order to match young learners' characteristics. An important modification was the exclusion of $\mathrm{C} 1$ and $\mathrm{C} 2$ levels of proficiency since they were too hard to adapt to learners' cognitive and communicative abilities (Tzevelekou et al., 2013).

With respect to test scoring, the maximum score for each test was 60,15 for each of the units mentioned above. Students would be placed at a specific level, if they scored at least half out of the total score corresponding to this level (Tzevelekou et al., 2013). An example of the scale used for students who undertook the first version of the test is given in Table 1. Most of the students in our study were placed at the B1 level, while some students were placed at the A2 and only a few at the B2 level. Due to the very small number of students being placed at the B2 level $(n=6)$, we decided to exclude this group of participants from our analysis. Further background information about participants' profile (i.e. proficiency level in Greek, chronological age,

\footnotetext{
${ }^{2}$ We included only the participants that their metadata matched with their written productions.

${ }^{3}$ It should be noted that the present study did not take into account any participants' language disorders, since no exclusion criteria were applied during the initial data collection.

${ }^{4}$ There was one more test administered to the first two grades of primary education but it is not mentioned here as it is beyond the scope of the present study.
}

6 Consortia Academia Publishing (A partner of Network of Professional Researchers and Educators) 
years of residence in Greece and years of attendance in the Greek and the Albanian educational setting) was retrieved from the metadata file and is all summarized in Table 2. The aforementioned information was collected by means of a questionnaire that was administered in the form of an interview between the researchers and the students.

Table 1

Classification of the results of the first version of the placement test

\begin{tabular}{cc}
$0-10$ & Not classified \\
$11-30$ & Preliminary Stage \\
$31-50$ & A1 \\
$51-60$ & A2 \\
\hline
\end{tabular}

Table 2

Participants' profile (means and SDs)

\begin{tabular}{ccccc}
\hline Proficiency & Age & $\begin{array}{c}\text { Years of residence } \\
\text { in Greece }\end{array}$ & $\begin{array}{c}\text { Years in Greek } \\
\text { educational setting }\end{array}$ & $\begin{array}{c}\text { Years in Albanian } \\
\text { educational setting }\end{array}$ \\
\hline A2 $(n=30)$ & $9.1(\mathrm{SD}=1.2)$ & $5.8(\mathrm{SD}=2.5)$ & $4.1(\mathrm{SD}=1.0)$ & $1(\mathrm{SD}=1.1)$ \\
$\mathrm{B} 1(n=61)$ & $12.6(\mathrm{SD}=2.5)$ & $6.1(\mathrm{SD}=3.5)$ & $4.9(\mathrm{SD}=2.3)$ & $3.1(\mathrm{SD}=3.0)$ \\
\hline
\end{tabular}

As we can infer from the mean scores in Table 2, students with higher proficiency in Greek were older than students with lower proficiency in Greek. In addition, B1 students had spent more time in both the Greek and the Albanian educational setting than A2 students, a difference which could easily be explained by the age difference between the two groups.

\subsection{Material}

The task used to collect participants' written productions that were analyzed in the present study was an elicitation narration task (part of the written production unit of both versions of the placement test), which tested students' written narrative skills by means of a series of black and white pictures (cf. Figure 1). The presented pictures were an adaptation of Hickmann's Cat Story (2003) and were later revised for the development of the Multilingual Assessment Instrument for Narratives (MAIN, Gagarina et al., 2012; for information on the Greek version of the tool see Tsimpli et al., 2020).

With regards to the procedure, students had to look at the six pictures that were presented all at once, and write a story. The phrase "Once upon a time" was already given in Greek as a start, and they were asked to continue the story. Students could look at the pictures during the whole time of their narration. Therefore, any effects of working memory are excluded.

Figure 1. The pictures used in the
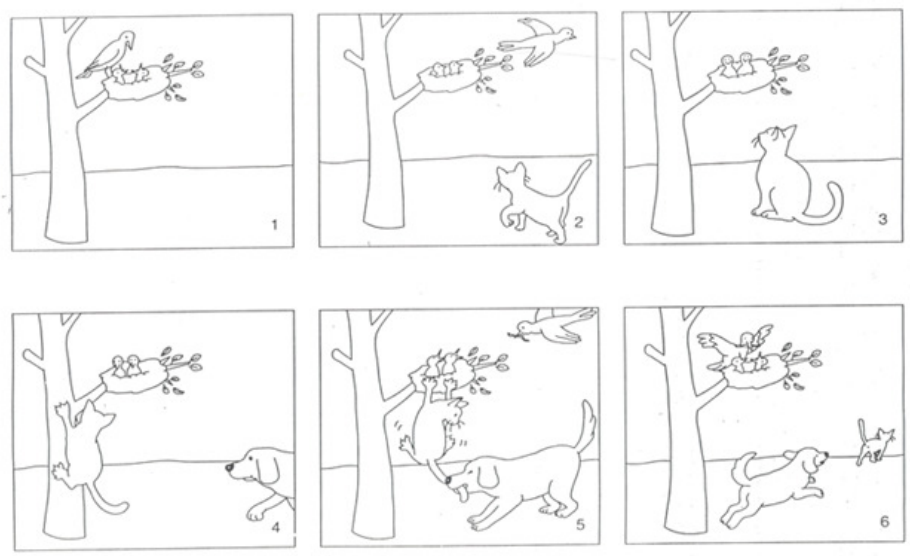

narration task 
As far as macrostructure is concerned, we calculated the Story Grammar score. In order to measure it, we divided the story in three episodes, each consisting of a Goal, an Attempt and an Outcome of the main character (cf. Table 3). Following Gagarina et al. (2012) and Tsimpli et al. (2020), we gave participants 1 point for each element they mentioned in each episode and 0 points for omitting the element. We also gave participants 1 point for mentioning information about the time and the place setting as well as for introducing each character of the episode, while 0 points if they did not mention them (Andreou, 2015). The sum of these points represented the final Story Grammar score.

Table 3

Story Grammar corresponding to the six pictures of the task

\begin{tabular}{|c|c|c|c|c|}
\hline Episode & Main character & Goal & Attempt & Outcome \\
\hline $1^{\text {st }}$ & Mother bird & $\begin{array}{l}\text { The mother bird wants } \\
\text { to feed the baby birds }\end{array}$ & $\begin{array}{l}\text { The mother bird } \\
\text { leaves the nest to find } \\
\text { food }\end{array}$ & $\begin{array}{l}\text { The mother bird } \\
\text { returns to the nest } \\
\text { with food }\end{array}$ \\
\hline $2^{\text {nd }}$ & Cat & $\begin{array}{l}\text { The cat wants to eat } \\
\text { the baby birds }\end{array}$ & $\begin{array}{l}\text { The cat tries to climb } \\
\text { the tree to reach the } \\
\text { baby birds }\end{array}$ & $\begin{array}{l}\text { The cat reaches the } \\
\text { nest }\end{array}$ \\
\hline $3^{\text {rd }}$ & Dog & $\begin{array}{l}\text { The dog wants to save } \\
\text { the baby birds }\end{array}$ & $\begin{array}{l}\text { The dog bites the cat's } \\
\text { tail to take it down }\end{array}$ & $\begin{array}{l}\text { The dog chases the cat } \\
\text { and the cat runs away }\end{array}$ \\
\hline
\end{tabular}

With regard to microstructure, following Andreou (2015), we investigated a variety of measures: (a) length of narration, (b) verb diversity ratio, (c) noun diversity ratio, (d) content words ratio, (e) function words ratio, (f) main clauses ratio and (g) subordinate clauses ratio. We measured the length of narration by counting the number of verbal clauses. Verb diversity ratio was counted by dividing the number of verb types to the number of verb tokens. Noun diversity ratio was counted by dividing the number of noun types to the number of noun tokens. Content words ratio was calculated by dividing the number of content words by the total number of words while function words ratio was calculated by dividing the number of function words by the total number of words. For the main clauses ratio, we divided the number of main clauses by the total number of verb clauses whereas for the subordinate clauses ratio we divided the number of subordinate clauses by the total number of verb clauses. For the purposes of the current study, we chose not to further analyze the subordinate clauses (adverbial, relative and complement). In order the results to be more comprehensible they are presented in percentages.

\section{Results}

\subsection{Language proficiency and macro and microstructure}

Macrostructure - In order to test our first research question, we first focused on the component of macrostructure, setting as the independent variable the language proficiency and as the dependent one the total score of Story grammar. Independent samples t-tests were conducted on raw scores. The results have indicated a group effect on the scores of Story Grammar $(t(89)=-3.565, p=.001)$. Hence, A2 group scored significantly lower $(65.3 \%)$ than the B1 group (74.2\%; cf. Figure 2$)$.

Delving into the results of Story Grammar the findings suggested that both groups, and particularly the A2 group, had difficulties setting the time (A2: 3\%; and B1: 11\%) and place (A2: 33\%; and B1: 63.9\%) of the story. In the setting of the time, the result is expected if we consider that the phrase "Once upon a time" was given.

On the contrary, all main characters were successfully introduced (both groups scored above 90\%). Similarly, the attempt of the episodes reached very high scores whereas the goal and the outcome were often not mentioned (cf. Table 4). The most problematic cases were detected in the outcome of the second episode for the A2 group

8 Consortia Academia Publishing (A partner of Network of Professional Researchers and Educators) 
and the goal of the third episode for both groups (cf. Table 4). The outcomes of the episodes, they seem to exhibit the greatest variation among Story Grammar components. More specifically, learners exhibit a very high accuracy in the outcome of the $3^{\text {rd }}$ episode while their performance decreases in the $1^{\text {st }}$ one and is even lower in the $2^{\text {nd }}$ episode.

Figure 2. Overall scores (\%) on Story Grammar (macrostructure) per proficiency level group

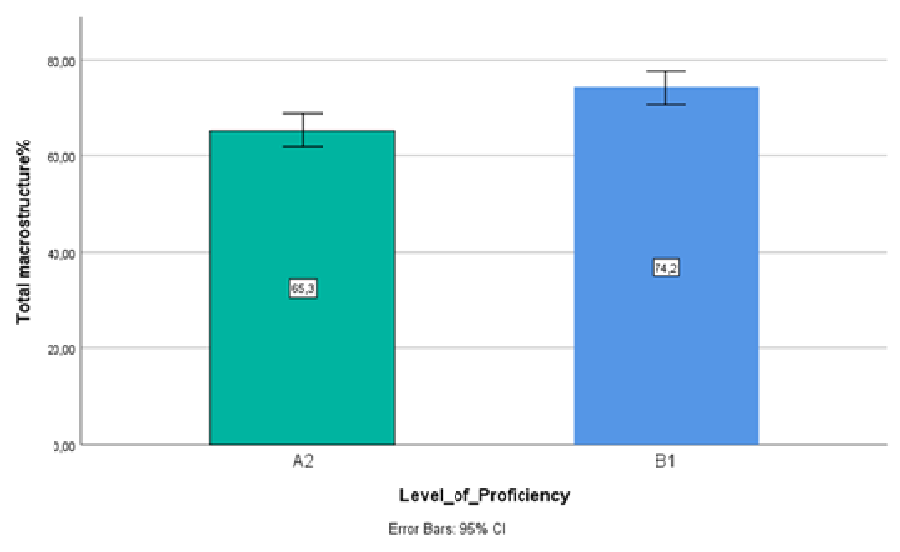

Table 4

Scores of the proficiency groups in Story Grammar

\begin{tabular}{c|ccccc}
\hline Setting time & A2 & $3 \%$ & & & \\
Setting place & B1 & $11 \%$ & & & \\
& A2 & $33 \%$ & & & \\
& B1 & $63.9 \%$ & & & \\
\hline Episode & \multicolumn{2}{|l}{ Main character } & Goal & Attempt & $60 \%$ \\
\hline $1^{\text {st }}$ & A2 & $93.3 \%$ & $47 \%$ & $93.3 \%$ & $67.2 \%$ \\
& B1 & $96.7 \%$ & $63.9 \%$ & $93.4 \%$ & $17 \%$ \\
$2^{\text {nd }}$ & A2 & $100 \%$ & $53.3 \%$ & $93.3 \%$ & $45.9 \%$ \\
& B1 & $98.3 \%$ & $70.4 \%$ & $90.1 \%$ & $90 \%$ \\
$3^{\text {rd }}$ & A2 & $100 \%$ & $33.3 \%$ & $97 \%$ & $95.1 \%$ \\
& B1 & $100 \%$ & $24.5 \%$ & $91.8 \%$ & \\
\hline
\end{tabular}

Microstructure - Turning to the impact of language proficiency on the second narrative component included in our first research question, microstructure, we also ran independent samples t-tests with (a) length of narratives, (b) main clauses ratio and subordinate clauses ratio, (c) content words ratio and function words ratio and (d) verb and noun diversity as dependent variables and language proficiency as independent variable. No differences were found in respect to the length of narratives $(t(89)=-.990, p=.325)$; hence the A2 group used roughly 14.2 verb clauses per narration, while the B1 group produced 15.2 verb clauses in their narrations.

In terms of the main clauses ratio and subordinate clauses ratio, there was a clear preference for the use of main clauses by both groups (for the A2 group: $77.5 \%$ and for the B1 group: $67.4 \%$; cf. Figure 3). Independent $t$-tests exhibited that the A2 group used more main clauses than the B1 group $(t(89)=2.798, p=.006)$. In the opposite fashion, with regards to the use of subordinate clauses, A2 used fewer subordinate sentences compared to the $\mathrm{B} 1$ group $(t(89)=2.790, p=.006)$.

Figure 3. Use of main and subordinate clauses $(\%)$ per proficiency group

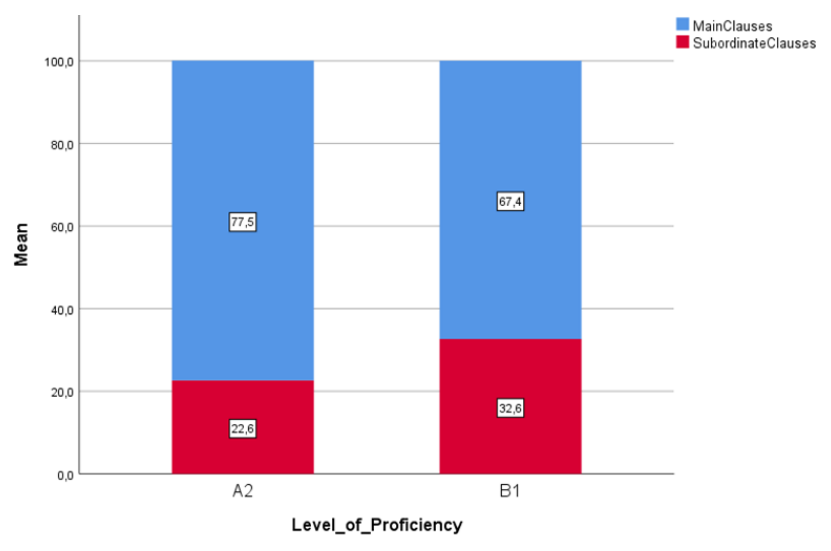


Concerning the use of content and function words, they seem to be rather equally used per group and between groups (cf. Figure 4). Subsequently, results have not indicated any group effect in the use of either content or function words $(t(89)=-.157, p=.876 ; t(89)=.157, p=.876$; respectively).

Figure 4. Use of content and function words $(\%)$ per proficiency group

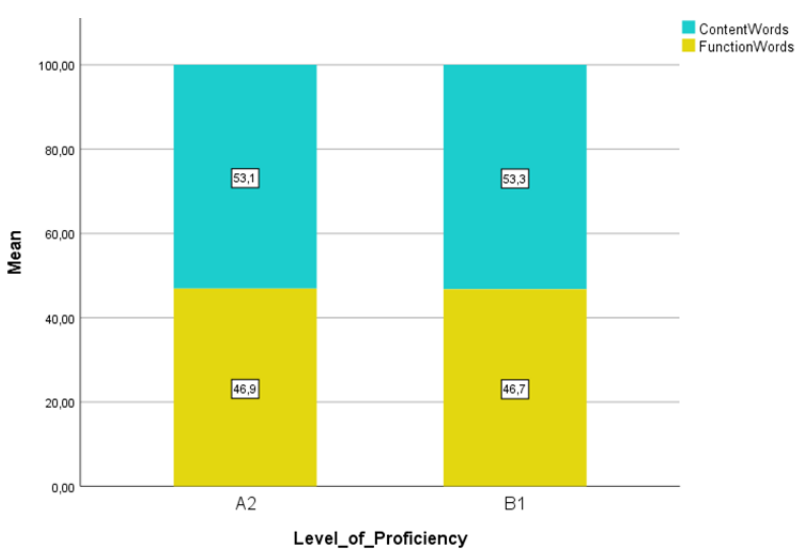

In terms of word diversity, the diversity in nouns is above $80 \%$ for both groups (A2: $89.4 \%$ and B1: $86.7 \%$ ), as Figure 5 depicts. No group effect was found for the noun diversity $(t(89)=.941, p=.349)$. On the other hand, in terms of the verb diversity, differences were observed between the groups $(t(89)=2.617, p=.012)$. Hence, the A2 group used a greater variety of verbs $(76.1 \%)$ compared to the B1 group (66.7\%). Paired-samples t-test have shown that in both groups noun diversity was higher compared to verb diversity (for the A2 group: $t(29)=$ $-3.056, p=.005$; for the B1 group: $t(60)=-8.747, p<.001)$.

Figure 5. Verb and noun diversity per proficiency group

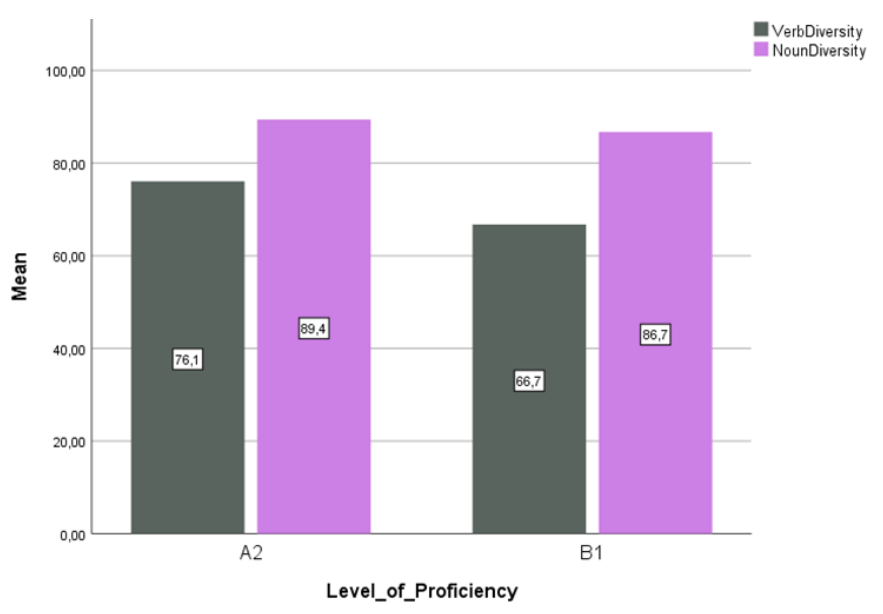

\subsection{Contextual factors and macro and microstructure}

With regards to our second research question, about correlations between contextual factors and macro- and microstructural features, we ran bivariate correlations. As variables were set the meta-data (years of residence in Greece, years in the Greek educational setting, years in Albanian educational setting, total proficiency scores and sub-scores of it, i.e. oral and written comprehension, grammar and written production of the placement test) and (a) Story Grammar score, (b) verb/noun diversity, (c) content/function words and (d) main/subordinate clauses.

Regarding the microstructural features, the use of main clauses negatively correlates with the scores on grammar and written production of placement test $(r(91)=-.237, p=.023 ; r(91)=-.293, p=.005$; respectively); thus, the more main clauses a student uses the poorer grammatical abilities and writing skills they have. By contrast, subordinate clauses have been found to correlate with written production of placement test $(r$ $(91)=.239, p=.023 ; r(91)=.292, p=.005$; respectively); hence, the better written production a student has, the more subordinate clauses they use. Finally, the noun diversity exhibited a link with the years of residence in Greece and the years of attendance at the Greek educational setting $(r(78)=.234, p=.039 ; r(89)=.218, p$ 
$=.040$; respectively).

\section{Discussion}

The current study examined, by means of GLC corpus, the role of language proficiency and contextual factors in some aspects of macrostructure and microstructure in L2 written narrative skills of L2 learners with Albanian origin. Below we will discuss the findings based on our initial hypotheses regarding scores in macroand microstructure and language proficiency and contextual factors.

\subsection{Language proficiency and macro and microstructure}

Macrostructure - Our first hypothesis concerned language proficiency and whether it would affect written narrative production in terms of both macrostructure and microstructure. Our hypothesis was only partially confirmed, since language proficiency did not affect all the aspects of macro- and microstructure under investigation.

In Story Grammar the results have shown that learners with higher proficiency (B1) manifested a better performance compared to learners with lower proficiency (A2) (in line with previous studies; Montanari, 2004; Viberg, 2011). In other words, the learners with higher proficiency were more accurate in presenting the setting of the story and the characters as well as their goals, attempts and outcomes in each episode. Thus, these results seem to be in line with previous studies highlighting that knowledge of the core grammar of a language is necessary for storytelling (Verhoeven, 2004) and that performance of students on standardized tests of language proficiency, such as the one used in the present study, can be an indicator of their narrative performance as well (Montanari, 2004). This result is interesting if we consider that macrostructure is considered a language independent component, concerning the higher order organization of a story (Andreou, 2015; Andreou \& Tsimpli, 2020). It should be noted though that Andreou and Tsimpli (2020) focused on bilinguals rather than L2 learners and that they examined their participants orally, while here a written-text procedure was used. In any case, as both theoretical (Cummins, 1976, 1979) and empirical work (Viberg, 2011) suggest, it is possible that even for such higher order skills to be successfully used during storytelling, a certain level of linguistic proficiency needs to be attained.

Apart from the discussion on the quantitative results in Story Grammar, it is interesting to qualitatively discuss and interpret them. Characters and their attempts were introduced successfully, since attempts represent the basic actions of the main characters which radically contribute to the story's continuation, they are rather prominent during narration and completely depictable (Andreou, 2015). On the other hand, goals appear to cause more difficulty to participants, especially to the lower proficiency ones. This observation is more prominent in the case of the $3^{\text {rd }}$ episode (for both groups) where the goal of the main character, i.e. the dog, is to save the baby birds from the cat. We assume that learners might be more affected by their world knowledge, in cases where they have to infer something which is not directly depicted on the pictures. Another possible alternative could be linked to the dog's facial expression. In other words, since the dog in pictures 5 and 6 is not very mean, children might have not been encouraged towards the interpretation that it got angry at the cat attacking the baby birds. This detail was corrected in the later version of the story for the MAIN tool (Gagarina et al., 2012). With regards to the outcomes of the episodes, they seem to exhibit the greatest variation among Story Grammar components. We consider rather straightforward the fact that the outcome of the last episode, i.e. the cat being chased away by the dog, representing the final scene of the story, is more salient and familiar to learners who must be used to finish their storytelling by providing a final solution to the main problem (Andreou, 2015). Concerning the outcome of the first episode, which causes some further difficulty, we could argue that since it is depicted in the last picture, it overlaps with the outcome of the $3^{\text {rd }}$ episode and is, thus, possibly overlooked due to the salience of the dog and the cat in the previous picture that is probably continued in the last one as well. What also contributes to this pattern, in our opinion, is the distance separating the last picture from the first two pictures of the story, which represent the goal and the attempt of the first episode. In other terms, it is possible that when 
reaching the end of the story learners have already forgotten the initial event, i.e. the mother bird leaving the nest to find food, causing the subsequent events of the story to unfold. Finally, in the outcome of the $2^{\text {nd }}$ episode the very low scores could be linked to the fact that the moment in which the cat reaches the nest is also the moment in which the dog bites its tail. As a result, the focus might automatically be put on the dog's action, probably causing the omission of the $2^{\text {nd }}$ episode's outcome. What is more, in the second episode we could again assume a weakness of the picture conveying the outcome, since in later versions of the story (Gagarina et al., 2012) the cat is represented trying to grasp a baby bird from the nest and not just reaching the nest, which could probably be confounded with the act of climbing the tree.

Microstructure - On the other hand, with regards to microstructural measures, proficiency was found to affect the use of main and subordinate clauses, i.e. learners with lower proficiency used more main clauses whereas students with higher proficiency used more subordinate clauses (Andreou, 2015; Andreou \& Tsimpli, 2020). This result is expected if we assume that the use of subordinate clauses in Greek requires knowledge of the respective conjunctions and their meaning and sometimes of the subjunctive form of verbs and all the morphophonological rules that are necessary for its correct realization. Since, the aforementioned linguistic properties are far more complicated than the coordinated use of clauses with verbs in indicative form, students with lower proficiency prefer the less demanding and complex structures with which they are already familiar (Uccelli \& Páez, 2007; Snow \& Uccelli, 2009). Performance in the written production also seems to affect the use of main and subordinate clauses although in an opposite fashion. Therefore, the findings exhibited that the lower the performance on the written production the more main clauses were used; by contrast, the higher the scores in the written production the higher is the use of subordinate clauses (Andreou \& Tsimpli, 2020). In a similar vein, if a learner had lower grammatical abilities (as depicted via the placement test) they tended to use more main clauses.

Another interesting finding in the level of microstructure is that learners overall exhibit greater diversity in the use of nouns than in the use of verbs. This could be possibly linked to the straightforward and linear unfolding of the story's events, where, apart from the return of the mother bird in the last picture, all characters act rather sequentially, minimizing in this way any need to be later reintroduced as main characters. In other words, we hypothesize that if the story comprised more pictures, i.e. more episodes, with the same characters, then this would contribute to a decrease in noun diversity, since it would result in increased references to the same protagonists. In the same vein, it is important to note that some of the verbs describing characters' main states or actions such as 'to be' or 'to come' were repeated across the story, thus causing the verb diversity to decrease.

As far as proficiency is concerned, verb diversity was found to be higher in A2 than in B1 level students. We consider this finding unexpected and we speculate that it might be explained by a possibly increased imaginative ability in the younger group of A2 learners compared to those of B1 level. In any case, we should assume that this ability remains within the limits of learners' lexical knowledge and it is subjected to further research.

Microstructural aspects that were not affected by language proficiency were length of narratives, noun diversity, content and function words which learners seem to use equally, regardless of their proficiency level. The finding might be explained by the "common underlying proficiency" (Cummins, 1967, 1979); thus, a difference might be evident in a higher proficiency level (i.e. B2). What is more, with regards to noun diversity we could assume that given the stable number of characters and of entities compiling the story's setting (a tree, a nest etc.), noun diversity is not expected to vary across proficiency levels, if we also take into account that words corresponding to the aforementioned properties are all known by learners.

\subsection{Contextual factors and macro and microstructure}

Our second hypothesis concerned the contextual factors and narrative skills; thus, we expected that biliteracy and residency in Greece would correlate with narrative production. Based on previous studies, we 
hypothesized that macro- and microstructure would be affected by both input (Viberg, 2001) and literacy practices (Karlsen et al., 2016). Our hypothesis was confirmed only in respect to noun diversity; hence, learners that have resided more years in Greece and have attended more years in the Greek educational setting exhibited a greater noun diversity in the stories. The finding is in line with previous studies (Snow \& Dickinson, 1990; Cain, 2003; Gorman et al., 2011; Karlsen et al., 2016) and is expected to the extent that vocabulary and particularly words, such as nouns, representing concrete entities, are prone to enhancement due to the increase of input in the L2, either in the school setting or in the broader social life. We assume that the absence of finding correlations between macrostructure and contextual factors might be since there was no information about parental book reading (as observed in previous studies, cf. Karlsen et al., 2016).

\section{Conclusions, limitations of the study and further research}

Concluding, our study adds value to the existing work on L2 written narratives. The findings suggested that language proficiency affect aspects of macro- and microstructure (Story Grammar, noun diversity, subordinate clauses). In addition, noun diversity correlated with literacy support in both languages and residence in the host country, suggesting that the more oral and written input the L2 learner receives the more diverse is their vocabulary, in terms of nouns. This finding indicates that the future research in L2 should steer to the examination of contextual factors and mainly equal literacy support.

The most significant contribution of the present study is that new knowledge is gained about narrative written production of L2 leaners of Greek and contextual factors (i.e., input and biliteracy). The importance of contextual factors has been verified by many studies on bilingualism (Andreou, 2015; Bongartz \& Torregrossa, 2017; Andreou \& Tsimpli, 2020). More specifically, studies on bilingualism, so far, have shown that contextual factors affect aspects of macrostructure (Andreou, 2015; Andreou \& Tsimpli, 2020); while some other studies in bilingual children have shown that language proficiency also affects aspects of microstructure (e.g. Tsimpli et al. 2016, Andreou \& Tsimpli 2020). Nevertheless, the contribution of these factors is less examined in the narratives of L2 learners, especially in terms of Greek as L2. Our results confirm those of Karlsen et al. (2016), who found that proficiency together with home literacy and exposure to L2 predict performance in microstructure measures. Thus, we believe that, through this study, the impact of input and literacy in both languages on language abilities of L2 learners will be highlighted and the future studies will move to this direction. To lesser, but still important, extent, another contribution of the study is that language proficiency in L2 affect not only microstructure (i.e. noun diversity and subordinate clauses), but also macrostructure (i.e. Story Grammar), in line with previous studies (Montanari, 2004; Viberg, 2011) and this adds value to data of Greek as a second language.

The findings of the present study have significant implications for researchers and educators. Researchers can be informed about the role of language profile of L2 learners in various languages using written narrative assessment. Moreover, they enhance their knowledge on the significant role of the contextual factors (i.e. input and biliteracy) and they can consider these factors as important variables for their future research. On the other hand, educators will be updated, since they will become more aware of L2 learners' difficulties and their work will be focused on both aspects of macro- and microstructure of narratives in order to aid their students. Because efficient second language teachers should be aware of research on L2 acquisition and adjust their methodological and educational decisions based on the sound knowledge coming from recent studies. In addition, the findings emerge that apart from educators, parents of L2 learners should be advised to promote their children's oracy and literacy in both languages. The aforementioned practices might give to L2 learners better chances for school and general academic success.

We should also acknowledge some limitations of the study. First, in the present study there was an unequal number of participants in the two groups of interest, namely the A2 and the B1 group, which consisted of 30 and 61 students accordingly. Although, this asymmetry might have affected the results, to some extent, we believe that the results highlight patterns that would not be easily reversed if the number of participants changed in either of the two groups. However, we consider that it would be of great interest to investigate more students of the B2 
level since this would favor meaningful comparisons between proficiency levels and would further elucidate issues in L2 narrative production. What would also render our study more complete is the investigation of narrative abilities in monolingual children with a similar profile, and the comparison of their performance with the performance of the L2 learners that is discussed in the present research. Another limitation is the lack of more information about participants' literacy practices at home or about their cognitive abilities. Such details could have possibly given rise to interesting correlations with macro- and microstructural measures and further highlight the role of contextual and cognitive factors in efficient storytelling.

Acknowledgement - We would like to acknowledge that this corpus is part of the outcomes of the project Diapolis and we would specially thank Professor Despina Papadopoulou and Assistant Professor Alexandros Tantos for giving us access to Greek Learner Corpus.

\section{Compliance with Ethical Standards}

Conflict of interest: The authors declare that they have no conflict of interest.

Ethical Approval: All procedures performed in studies involving human participants were in accordance with the ethical standards of the institutional Ethics Committee of Aristotle University of Thessaloniki and/or national research committee and with the 1964 Helsinki declaration and its later amendments or ethical standards

\section{References}

Andreou, M. (2015). The effects of bilingualism on verbal and non-verbal cognition: The micro- and macro-structure of narratives in the weak and the dominant language of the bilingual child [Unpublished PhD Thesis]. Aristotle University of Thessaloniki.

Andreou, M., \& Tsimpli, I. M. (2020). Bilingualism, biliteracy and syntactic complexity: the role of crosslinguistic influence and cognitive skills. Language Acquisition, Processing and Bilingualism, TRT7.

Bedore, L. M., Pena, E. D., Summers, C. L., Boerger, K. M., Resendiz, M. D., Greene, K., Bohman, T. M., \& Gillam, R. B. (2012). The measure matters: Language dominance profiles across measures in Spanish-English bilingual children. Bilingualism: Language and Cognition, 15, 616-629. https://doi.org/10.1017/S1366728912000090

Bliss, L. S., McCabe, A., \& Miranda, E. A. (1998). Narrative assessment profile: Discourse analysis for school-age children. Journal of Communication Disorders, 31(4), 347-363. https://doi.org/10.1016/S0021-9924(98)00009-4

Bongartz, C. (2016). Bilingual and Second Language Development and Literacy - Emerging Perspectives on an Intimate Relationship. In M. Mattheoudakis, \& K. Nicolaidis (Eds.), Selected Papers on Theoretical and Applied Linguistics from ISTAL 21 (pp. 3-42). Thessaloniki: School of English, Aristotle University of Thessaloniki.

Bongartz, C., \& Torregrossa, J. (2017). The effects of balanced biliteracy on Greek-German bilingual children's secondary discourse ability. International Journal of Bilingual Education and Bilingualism, 1-16. https://doi.org/10.1080/13670050.2017.1355888

Botting, N. (2002). Narrative as a tool for the assessment of linguistic and pragmatic impairments. Child Language Teaching and Therapy, 18(1), 1-21. https://doi.org/10.1191\%2F0265659002ct224oa

Bus, A. G., van Ijzendoorn, M. H., \& Pellegrini, A. D. (1995). Joint book reading makes for success in learning to read: A meta-analyses on intergenerational transmission of literacy. Review of Educational Research, 65(1), 1-21. https://doi.org/10.3102/00346543065001001

Cain, K. (2003). Text comprehension and its relation to coherence and cohesion in children's fictional narratives. British Journal of Developmental Psychology, 21, 335-351. https://doi.org/10.1348/026151003322277739

Chondrogianni, V., \& Marinis, T. (2011). Differential effects of internal and external factors on the development

14 Consortia Academia Publishing (A partner of Network of Professional Researchers and Educators) 
Effects of language proficiency and contextual factors on second language learners' written narratives

of vocabulary, tense morphology and morpho-syntax in successive bilingual children. Linguistic Approaches to Bilingualism, 1, 318-342. https://doi.org/10.1075/lab.1.3.05cho

Council of Europe. (2001). Common European framework of reference for languages. Cambridge: Cambridge University Press.

Cummins, J. (1976). The influence of bilingualism on cognitive growth a synthesis of research findings and explanatory hypotheses. Working Papers on Bilingualism, 9, 1-43.

Cummins, J. (1979). Linguistic interdependence and the educational development of bilingual children. Review of Educational Research, 49, 222-251. https://doi.org/10.3102/00346543049002222

Curenton, S. M., \& Justice, L. M. (2004). African American and Caucasian preschoolers' use of decontextualized language: Literate language features in oral narratives. Language, Speech, and Hearing Services in Schools, 35, 240-253. https://doi.org/10.1044/0161-1461(2004/023)

De Houwer, A. (2014). The absolute frequency of maternal input to bilingual and monolingual children: A first comparison. In T. Grüter \& J. Paradis (Eds.), Input and experience in bilingual development (pp. 37-58). Amsterdam: John Benjamins. https://doi.org/10.1075/tilar.13.03deh

Dulay, H., Burst, M., \& Krashen, S. (1982). Language two. New York: Oxford University Press.

Durgunoğlu, A. Y. (2002). Cross-linguistic transfer in literacy development and implications for language learners. Annals of Dyslexia, 52, 189-204. https://doi.org/10.1007/s11881-002-0012-y

Evans, M. D. R., Kelley, J., Sikora, J., \& Treiman, D. J. (2010). Family scholarly culture and educational success: Books and schooling in 27 nations. Research in Social Stratification and Mobility, 28(2), 171-197. https://doi.org/10.1016/j.rssm.2010.01.002

Fang, Z. (2001). The development of schooled narrative competence among second graders. Reading Psychology, 22(3), 205-223. https://doi.org/10.1080/027027101753170629

Francis, N. (2006). The development of secondary discourse ability and metalinguistic awareness in second language learners. International Journal of Applied Linguistics, 16(1), 37-60. https://doi.org/10.1111/j.1473-4192.2006.00105.x

Gagarina N., Klop, D., Kunnari, S., Tantele, K., Välimaa, T., Balèiûnienë, I., Bohnacker, U., \& Walters, J. (2012). MAIN: Multilingual Assessment Instrument for Narratives. ZAS Papers in Linguistics, 56. Berlin: ZAS.

Gagarina, N. (2016). Narratives of Russian-German preschool and primary school bilinguals: Rasskaz and Erzaehlung. Applied Psycholinguistics, 37(1), 91-122. https://doi.org/10.1017/S0142716415000430

Gorman B. K., Fiestas, E., Peña, E. D., \& Reynolds, M. (2011). Creative and stylistic devices employed by children during a storybook narrative task: A cross-cultural study. Language, Speech, and Hearing Services in Schools, 42, 167-181. https://doi.org/10.1044/0161-1461(2010/10-0052)

Grosjean, F. (1989). The bilingual as a person. In R. Titone (Ed.), On the bilingual person. Ottawa: Canadian Society for Italian Studies.

Gutiérrez-Clellen, V. (2002). Narratives in two languages: Assessing performance of bilingual children. Linguistics and Education, 13(2), 175-197. https://doi.org/10.1016/S0898-5898(01)00061-4

Hadley, P. A. (1998). Language sampling protocols for eliciting text-level discourse. Language, Speech, and Hearing Services in Schools, 29(3), 132-147. https://doi.org/10.1044/0161-1461.2903.132

Heilmann, J., Miller, J. F., \& Nockerts, A. (2010). Sensitivity of narrative organization measures using narrative retells produced by young school-age children. Language Testing, 27(4), 603-626. https://doi.org/10.1177\%2F0265532209355669

Hellenic Statistical Authority (2014). Announcement of the demographic and social characteristics of the Resident Population of Greece according to the 2011 Population - Housing Census [Press Release]. https://www.statistics.gr/documents/20181/1215267/NWS_census2011_rev_en.pdf/9ed5296a-2809-440 3-9210-d9f303cbcad5

Hickmann, M. (2003). Children's discourse: Person, space and time across languages. Cambridge: Cambridge University Press.

Hickmann, M. (2004). Coherence, cohesion, and context: Some comparative perspectives in narrative development. In S. Strömqvist \& L. Verhoeven (Eds.), Relating events in narrative: typological and contextual perspectives (pp. 281-306). Mahwah, NJ: Erlbaum. 
Hughes, D., McGillivray, L., \& Schmidek, M. (1997). Guide to narrative language: Procedures for assessment. Eau Claire, WI: Thinking Publications.

Johnson, J., \& Newport, E. (1989). Critical period effects in second language learning: The influence of maturational state on the acquisition of ESL. Cognitive Psychology, 21, 60-99.

https://doi.org/10.1016/0010-0285(89)90003-0

Karlsen J., Geva, E., \& Lyster, S.-A. (2016). Cognitive, linguistic, and contextual factors in Norwegian second language learner's narrative production. Applied Psycholinguistics, 37(5), 1117-1145. Cambridge: Cambridge University Press. https://doi.org/10.1017/S014271641500051X

Kintsch, W., \& van Dijk, T. A. (1978). Toward a model of text comprehension and production. Psychological Review, 85(5), 363-394. https://doi.org/10.1037/0033-295X.85.5.363

Kroffke, S., \& Rothweiler, M. (2006). Variation im frühen Zweitspracherwerb des Deutschen durch Kinder mit türkischer Erstsprache. In M. Vliegen (Ed.), Variation in sprachtheorie und spracherwerb. Akten des 39. Linguistischen Kolloquiums (pp. 145-153). Amsterdam. Frankfurt a. M.: Lang.

Lenneberg, E. H. (1967). Biological foundations of language. Wiley.

Leseman, P. M., \& de Jong, P. F. (1998). Home literacy: Opportunity, instruction cooperation and social-emotional quality predicting early reading achievement. Reading Research Quarterly, 33(3), 294-318. https://doi.org/10.1598/RRQ.33.3.3

Liles, B. Z., Duffy, R. J., Merritt, D. D., \& Purcell, S. L. (1995). Measurement of narrative discourse ability in children with language disorders. Journal of Speech and Hearing Research, 38(2), 415-425. https://doi.org/10.1044/jshr.3802.415

McCabe, A. (1996). Evaluating narrative discourse skills. In K. Cole, P. Dale, \& D. Thal (Eds.), Assessment of communication and language (pp. 121-141). Baltimore, MD: Paul H. Brooks.

McCabe, A., \& Peterson, C. (1984). What makes a good story? Journal of Psycholinguistic Research, 13(6), 457-480.

McCabe, A., \& Rollins, P. R. (1994). Assessment of preschool narrative skills. American Journal of Speech Language Pathology, 3(1), 45-56. https://doi.org/10.1044/1058-0360.0301.45

Meisel, J. M. (2008). Child second language acquisition or successive first language acquisition? In B. Haznedar, \& E. Gavruseva (Eds.), Current trends in child second language acquisition: A generative perspective (pp. 55-80). Amsterdam: John Benjamins. https://doi.org/10.1075/lald.46.04mei

Meisel, J. M. (2009). Second language acquisition in early childhood. Zeitschrift für Sprachwissenschaft, 28, 5-34. https://doi.org/10.1515/ZFSW.2009.002

Miller, J. F. (1981). Assessing language production in children. Baltimore: University Park Press.

Miller, J. F., Heilmann, J., Nockerts, A., Iglesias, A., Fabiano, L., \& Francis, D. J. (2006). Oral language and reading in bilingual children. Learning Disabilities Research and Practice, 21(1), 30-43. https://doi.org/10.1111/j.1540-5826.2006.00205.x

Montanari, S. (2004). The development of narrative competence in the L1 and L2 of Spanish-English bilingual children. International Journal of Bilingualism, 8, 449-497. https://doi.org/10.1177/13670069040080040301

Nippold, M. A., Ward-Lonergan, J. M., \& Fanning, J. L. (2005). Persuasive writing in children, adolescents, and adults: A study of syntactic, semantic, and pragmatic development. Language, Speech, and Hearing Services in Schools, 36, 125-138. https://doi.org/10.1044/0161-1461(2005/012)

Pearson, B. Z. (2002). Narrative competence among monolingual and bilingual school children in Miami. In K. D. Oller, \& R. E. Eilers (Eds.), Language and literacy in bilingual children (pp. 135-174). Clevedon: Multilingual Matters. https://doi.org/10.21832/9781853595721-008

Premack, D., \& Woodruff, G. (1978). Cognition and consciousness in nonhuman species - Reply. Behavioral and Brain Sciences, 1(4), 616-628.

Rothweiler, M. (2006). The acquisition of V2 and subordinate clauses in early successive acquisition of German. In C. Lleo (Ed.), Interfaces in multilingualism (pp. 91-113). Amsterdam: John Benjamins. https://doi.org/10.1075/hsm.4.05rot

Rydland, V., Grøver, V., \& Lawrence, J. (2014). The second-language vocabulary trajectories of Turkish

16 Consortia Academia Publishing (A partner of Network of Professional Researchers and Educators) 
Effects of language proficiency and contextual factors on second language learners' written narratives

immigrant children in Norway from ages five to ten: The role of preschool talk exposure, maternal education and co-ethnic concentration in the neighborhood. Journal of Child Language, 41, 352-381. https://doi.org/10.1017/S0305000912000712

Schneider, P., Hayward, D., \& Dubé, R. V. (2006). Storytelling from pictures using the Edmonton narrative norms instrument. Journal of Speech Language Pathology and Audiology, 30(4), 224.

Schuele, M. C., \& Tolbert, L. (2001). Omissions of obligatory relative markers in children with specific language impairment. Clinical Linguistics \& Phonetics, 15(4), 257-274. https://doi.org/10.1080/02699200010017805

Schwartz, B. D. (2004). On child L2 development of syntax and morphology. Lingue e Linguaggio, 3, 97-132. https://doi.org/10.1418/13315

Scott, C. M., \& Stokes, S. L. (1995). Measures of syntax in school-age children and adolescents. Language, Speech, and Hearing Services in Schools, 26(4), 309-319. https://doi.org/10.1044/0161-1461.2604.309

Snow, C., \& Dickinson, D. K. (1990). Social sources of narrative skills at home and at school. First Language, 10, 87-103. https://doi.org/10.1177/014272379001002901

Snow, C., \& Uccelli, P. (2009). The challenge of academic language. In D. R. Olson \& N. Torrance (Eds.), The Cambridge handbook of literacy (pp. 112-133). Cambridge: Cambridge University Press. https://doi.org/10.1017/CBO9780511609664.008

Sopata, A. (2010). Inflectional morphology in child second language acquisition. In J. Costa, A. Castro, M. Lobo, \& F. Pratas (Eds.), Language Acquisition and Development. Proceedings of GALA 2009 (pp. 419-429). Cambridge: Cambridge Scholars Publishing.

Squires, K. E., Lugo-Neris, M. J., Pẽna, E. D., Bedore, L. M., Bohman, T. M., \& Gillam, R. B. (2014). Story retelling by bilingual children with language impairments and typically developing controls. International Journal of Communication Disorders, 49, 60-74. https://doi.org/10.1111/1460-6984.12044

Stein, N. L., \& Glenn, C. G. (1978). An analysis of story comprehension in elementary school children. In R. O. Freedle (Ed.), New directions in discourse processing (Vol. 2, pp. 53-120). Norwood NJ: Ablex.

Swanson, L. A., Fey, M. E., Mills, C. E., \& Hood, L. S. (2005). Use of narrative-based language intervention with children who have specific language impairment. American Journal of Speech-Language Pathology, 14, 131-143. https://doi.org/10.1044/1058-0360(2005/014)

Tager-Flusberg, H., \& Sullivan, K. (1994). Predicting and explaining behavior: A comparison of autistic, mentally retarded and normal children. Journal of Child Psychology and Psychiatry, 35, 1059-1075. https://doi.org/10.1111/j.1469-7610.1994.tb01809.x

Tantos, A., \& Papadopoulou, D. (2014). Stand-off annotation in learner corpora: Compiling the Greek Learner Corpus (GLC). In A. Diaz-Negrillo, \& F. Diaz-Pérez (Eds.), Specialisation and Variation in Language Corpora (pp. 15-40). Bern: Peter Lang. https://doi.org/10.3726/978-3-0351-0713-5

Teale, W. H., \& Sulzby, E. (1986). Emergent literacy: Writing and reading. Norwood, NJ: Ablex.

Templin, M. C. (1957). Certain language skills in children. Minneapolis: University of Minnesota Press.

Tsimpli, I. M., Andreou, M., \& Peristeri, E. (2020). The multilingual assessment instrument for narratives: Greek. ZAS Papers in Linguistics, 64, 101-106. https://doi.org/10.21248/zaspil.64.2020.562

Tsimpli, I., Peristeri, E., \& Andreou, M. (2016). Narrative production in monolingual and bilingual children with specific language impairment. Applied Psycholinguistics, 37(1), 195-216. https://doi:10.1017/S0142716415000478

Tzevelekou, M., Giagkou, M., Kantzou, V., Stamouli, S., Varlokosta, S., Mitzias, I., \& Papadopoulou, D. (2013). Second language assessment in the Greek educational system: The case of Reception Classes. Glossologia, 21, 75-89.

Uccelli, P., \& Páez, M. M. (2007). Narrative and vocabulary development of bilingual children from kindergarten to first grade: Developmental changes and associations among English and Spanish skills. Language, Speech, and Hearing Services in Schools, 38(3), 225-36. https://doi.org/10.1044/0161-1461(2007/024)

Unsworth, S. (2005). Child L2, Adult L2, Child L1: Differences and similarities. A study on the acquisition of 
direct object scrambling in Dutch [PhD dissertation]. Utrecht University.

Unsworth, S. (2014). Comparing the role of input in bilingual acquisition across domains. In T. Grüter, \& J. Paradis (Eds.), Input and experience in bilingual development (pp. 181-201). Amsterdam: John Benjamins. https://doi.org/10.1075/tilar.13.10uns

Unsworth, S. (2016). Quantity and quality of language input in bilingual language development. In E. Nicoladis, \& S. Montanari (Eds.), Lifespan perspectives on bilingualism (pp. 136-196). Berlin: Mouton de Gruyter/APA. https://doi.org/10.1037/14939-007

Viberg, A. (2001). Age- and L2-related features in bilingual narratives in Sweden. In L. Verhoeven, \& S. Strömqvist (Eds.), Narrative development in a multilingual context. Amsterdam: John Benjamins. https://doi.org/10.1075/sibil.23.04vib

Walach, G. P. (2008). Language intervention for school-age students: Setting goals for academic success. St. Louis, MO: Mosby.

Westby, C. E. (2005). Assessing and facilitating text comprehension problems. In H. Catts, \& A. Kamhi (Eds.), Language and reading disabilities (pp. 157-232). Boston: Allyn \& Bacon. 